\title{
Investigating the effect of selective logging on tree biodiversity and structure of the tropical forests of Papua New Guinea
}

Riccardo Testolin ${ }^{(1)}$, Simon Saulei ${ }^{(2)}$, Alessio Farcomeni ${ }^{(3)}$, Giorgio Grussu ${ }^{(1-4)}$, Cossey Yosi ${ }^{(2)}$, Michele De Sanctis ${ }^{(4)}$, Fabio Attorre $^{(4)}$

\section{Introduction}

Tropical forests cover less than $10 \%$ of the global land area though likely harbor more

\begin{abstract}
Unsustainable exploitation of tropical forest resources is raising worldwide concern. In Papua New Guinea (PNG) timber harvesting has been identified as a major contributor to deforestation and forest degradation but its impact on biodiversity is still poorly understood. In this study we investigated the effect of selective logging on tree taxonomic composition, structure and diversity of PNG forests. We used data from 101 one-hectare permanent sample plots (PSPs) belonging to two vegetation types: low altitude forests on plains and fans (type $\mathrm{P}$ ) and low altitude forests on uplands (type $\mathrm{H}$ ). We used multivariate techniques to test for significant differences in species composition between plots of different vegetation types and disturbance regimes, identifying the tree taxa to which these differences could be ascribed. ANOVA was used to test for differences between logged-over and unlogged forest PSPs with respect to biodiversity (richness, Shannon's diversity, Pielou's evenness) and stand structure (stem density, basal area - BA). Temporal trends of forest features were analyzed using linear regression. Significant differences in taxonomic composition were found between logged-over and unlogged plots of the $H$ type $(p=0.04)$. No differences were found in richness, diversity and evenness between logged-over and unlogged forest plots, while stem density was higher in the latter $\left(421 \pm 153\right.$ stems ha-1 $\left.^{-1}\right)$. Greater BA was found in unlogged forests $\left(30.28 \pm 4.45 \mathrm{~m}^{2} \mathrm{ha}^{-1}\right)$ of the $\mathrm{H}$ type when compared to the logged-over stands $\left(15.52 \pm 4.04 \mathrm{~m}^{2} \mathrm{ha}^{-1}\right)$. We detected positive trends in richness $(0.55 \pm$ 0.19 taxa ha $^{-1} \mathrm{yr}^{-1}$ ) and diversity after logging. Furthermore, $\mathrm{H}$ type forest exhibited positive trends in stem density $\left(9 \pm 1\right.$ stems ha $\left.{ }^{-1} \mathrm{yr}^{-1}\right)$ and BA $(0.42 \pm$ $0.06 \mathrm{~m}^{2} \mathrm{ha}^{-1} \mathrm{yr}^{-1}$ ) with elapsed time since harvesting. Our analysis highlights some significant effects of logging activities on biodiversity and structure of PNG forests. Additionally, forests exhibited a significant recovery with respect to richness, diversity and stand structure. These preliminary results will be compared with data collected by the forthcoming National Forest Inventory in order to assess and monitor the effects of human activities and ecological factors on PNG forest biodiversity and develop appropriate conservation measures and sustainable management strategies.
\end{abstract}

Keywords: Selective Logging, Biodiversity, Basal Area, Papua New Guinea, Multivariate Analysis, National Forest Inventory, Permanent Sample Plots, REDD+ than half of all species on Earth. The island of New Guinea possesses the third largest tropical rainforest on the planet after the $\square$ (1) Food and Agriculture Organization of the United Nations, v.le delle Terme di Caracalla, I-00153, Roma (Italy); (2) Papua New Guinea Forest Research Institute, P.O. Box 314, Lae 411, Morobe Province, Papua (New Guinea); (3) Department of Public Health and Infectious Diseases, "Sapienza" University of Rome, p.le Aldo Moro 5, I-00185 Roma (Italy); (4) Department of Environmental Biology, "Sapienza” University of Rome, p.le Aldo Moro 5, I-00185 Roma (Italy)

@ Riccardo Testolin (riccardo.testolin@gmail.com)

Received: Jun 05, 2015 - Accepted: Nov 01, 2015

Citation: Testolin R, Saulei S, Farcomeni A, Grussu G, Yosi C, De Sanctis M, Attorre F (2016). Investigating the effect of selective logging on tree biodiversity and structure of the tropical forests of Papua New Guinea. iForest 9: 475-482. - doi: 10.3832/ifor1732-008 [online 201601-25]

Communicated by: Gianluca Piovesan
Amazon and the Congo Basin. About half of that forest belongs to Papua New Guinea (PNG) with about 33 Mha covered by closed natural forest (Keenan et al. 2011). The forests of PNG have been ranked among the world's ten most ecologically distinctive forest regions (Bryant et al. 1997, Olsen \& Dinerstein 1998, Brooks et al. 2006), accounting for an estimated $6 \%$ of the world biodiversity (Davis et al. 1995, Borden \& Ward 2006, Kinch et al. 2010) and providing habitat for approximately 11000 plant species currently described, and some $9000-14000$ yet to be discovered (Supriatna et al. 1999).

Deforestation and forest degradation are listed among the main causes of species loss in biodiversity hotspots (Myers et al. 2000, Pimm \& Raven 2000, Stork 2010), particularly in tropical areas. However, well managed logged forests still provide many important ecological services such as carbon sequestration, soil erosion control, 
water regime regulation (Edwards et al. 2014, Bicknell et al. 2015) and are home to numerous animal and plant species (Edwards et al. 2011, Putz et al. 2012). In PNG, logging operations have suffered in the past from poor performance and a high level of corruption (APAG 1990, Filer \& Sekhran 1998), which finally led to the passing of the National Forestry Act of 1991 (PNGFA 1991), aiming to provide regulations for a more sustainable supply of timber.

Nonetheless, logging of native forests in PNG is still criticized for a host of unsustainable practices (Laurence et al. 2010, Lindemalm \& Rogers 2013). Timber concessions usually exceed 80000 ha each and the timber removed during harvesting operations averages about $15 \mathrm{~m}^{3} \mathrm{ha}^{-1}$, while the planned return period is usually of $35-40$ years (Keenan et al. 2005). Previous studies questioned the sustainability of current logging practices, without achieving unanimous agreement as for the rate and extent of deforestation and forest degradation. Shearman et al. $(2008,2009)$ highlighted a net loss of $15.0 \%$ of primary rain forest - at an annual rate of $1247 \mathrm{~km}^{2}$ - and a degradation of $8.8 \%$ to secondary forest between 1972 and 2002. On the other hand, Filer et al. (2009) criticized the former and reported the lower deforestation rate by Bellamy \& McAlpine (1995) - $392 \mathrm{~km}^{2}$ per year - as more reliable. Nevertheless, they acknowledged the complex long-term effects of timber harvesting on forest carbon stocks.

In order to address such issues, remuneration for forest values such as carbon sequestration capacity has generated much interest in PNG, particularly as an alternative income source to large-scale timber harvesting (Fox et al. 2011a). In this res- pect, useful data will be provided by the forthcoming multipurpose National Forest Inventory (NFI), which will be a key component of the National Forest Monitoring System that PNG is required to establish for Reducing Emission from Deforestation and Forest Degradation (REDD+). REDD+ is an expected mechanism under the United $\mathrm{Na}$ tions Framework Convention on Climate Change (UNFCCC), which consists in a wide range of activities aimed at preserving forest carbon stock, as well as promoting biodiversity conservation (Howes 2009, Melik 2010, Grussu et al. 2014).

With this study we aimed to contribute to PNG'S REDD+ preparedness activities by providing a first insight on the effect of selective logging on forest biodiversity. To that end, we analyzed data from an existing set of Permanent Sample Plots (PSPs) that was established to assist planning of forest management options (Alder et al. 1999) and to provide a ground-based estimation of forest $C$ and $C$ flux associated with selective logging (Fox et al. 2010, 2011b). We used PNG's PSP data to shed light on the impact of selective logging on PNG's forest structure as well as on tree taxonomic diversity, which has shown a significant cross-taxon congruency and can therefore be considered as a proxy for other taxonomic groups (Howard et al. 1998, Kati et al. 2004, Barlow et al. 2007). In particular, we sought to: (1) determine the effect of selective-logging on tree taxonomic composition by using multivariate analyses techniques; (2) assess the impact of selective-logging on indicators such as forest structure, richness, diversity and evenness: (3) analyze changes of these indicators in relation to the years after logging (YAL).

The sampling scheme of the existing PSPs

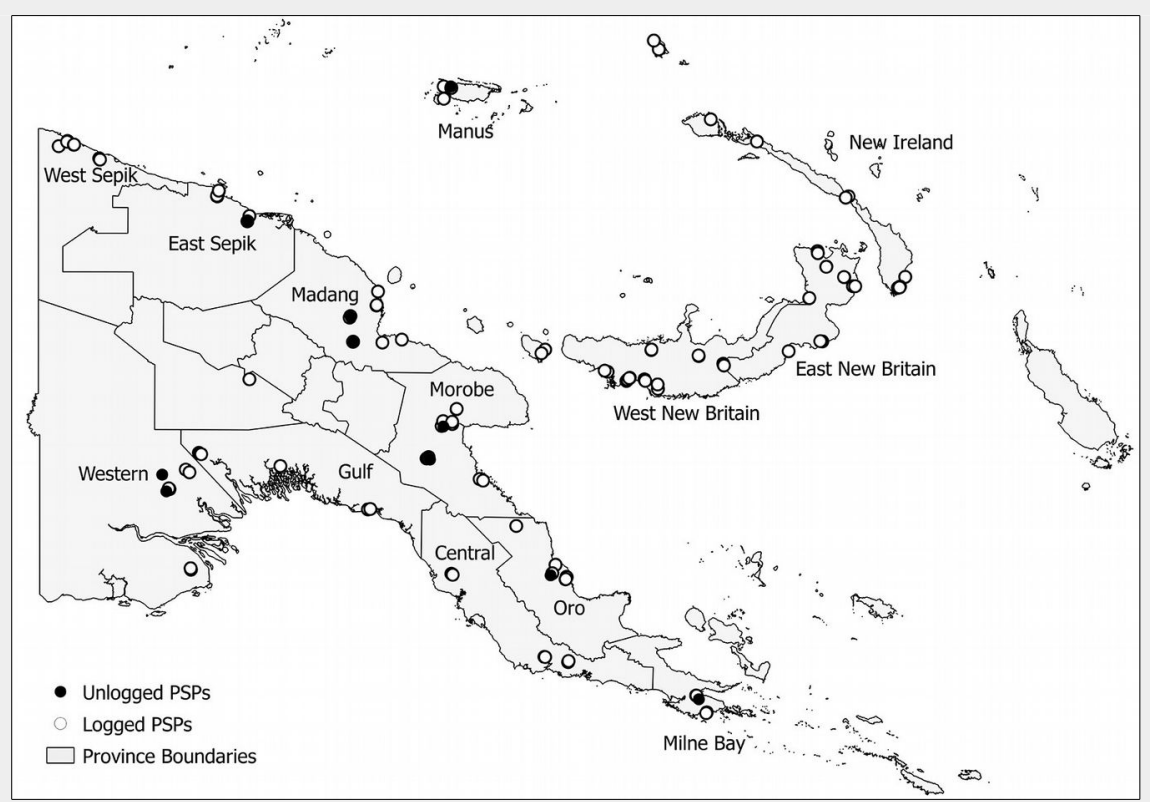

Fig. 1 - Map of PNG showing PSP locations across the country. Empty circles represent 122 logged-over PSPs, while 13 unlogged PSPs are represented by black circles. Province boundaries as well as province names are shown. was not meant to provide an assessment of the effect of forest management on biodiversity in such a wide and heterogeneous area as PNG. A systematic assessment and a clear experimental design are lacking, which makes it difficult to go beyond the analyses described in this paper. Since only a few studies have been carried out to this purpose, some of which were limited to specific regions (Saulei 1984, Lindemalm \& Rogers 2013) and some focused on stand structure rather than biodiversity (Yosi et al. 2011), we decided to conduct a first extensive preliminary evaluation despite the current limitations, to inform the design of the forthcoming NFI.

\section{Materials and methods}

\section{Dataset}

\section{Background}

One hundred and thirty five PSPs (Fig. 1) were established and measured by the PNG Forest Research Institute (PNGFRI) between 1992 and 2008. Most PSPs were located in lowland tropical forests $(<1000$ $m$ a.s.l.) distributed throughout PNG where most harvesting activities took place. Only ten plots were established in montane forests. Annual rainfall in all these plots averages over $3000 \mathrm{~mm} \mathrm{yr}^{-1}$. Plots were located on a range of soil groups, with the most common being Alfisols, Entisols, Inceptsols, and Mollisols (Pokana 2002). The plots were established in pairs, usually within $1 \mathrm{~km}$ of each other, according to the procedures adapted from Alder \& Synnott (1992) which are reported in PNGFRI (unpublished 1994). Each plot is 1 ha $(100 \times 100$ $\mathrm{m}$ ) in size and subdivided in 25 sub-plots of $20 \times 20 \mathrm{~m}$, where all stems $\geq 10 \mathrm{~cm}$ diameter at breast height (DBH) are mapped and identified to genus or species level. Measurements taken on trees included DBH and height. The data has previously been collated, cleaned and transferred into a Microsoft Access ${ }^{\oplus}$ database (Fox \& Keenan 2010). A total of 122 plots were established in selectively harvested forests, usually $0-4$ YAL (although 7 PSPs were established from 6 to $13 \mathrm{YAL}$ ), and were specifically intended to monitor forest recovery and re-growth. Only 13 PSPs were located in unlogged forests.

\section{PSP used in the study}

Despite the precise field procedure some problems occurred during preliminary analysis of data. Twenty four PSPs were labeled as burnt by fires associated with El Niño Southern Oscillation (ENSO) drought event of 1997/1998 (Barr 1999, Fox et al. 2010, 2011b), which could have influenced the number and abundance of tree species in the plots. Thus, these plots were not included in our analyses. Moreover, montane forests were under-represented with only 10 PSPs, of which just two located in unlogged forests. Hence, to avoid biased results, we carried out the analyses on a 
set of 101 unburned lowland forest PSPs for a total of 342 censuses with 119404 tree measurements (32 243 stems recorded at the first census). Stems were identified either to genus or species level, for a total of 527 taxa. Due to the current incomplete taxonomic knowledge of tree species in PNG and the difficulties their identification, this limitation is expected to occur in all forest surveys so that our results are comparable with those from previous similar studies (see Yosi et al. 2011) or from the forthcoming NFI.

\section{Forest vegetation types}

To account for differences among vegetation types (VTs), the PSPs were superimposed on a PNG vegetation map (JICAPNGFA 2014) and the corresponding VT was recorded. The 101 plots were distributed into two different lowland VTs: 49 PSPs (6 in unlogged forests) in low altitude forest on plains and fans (P), and 52 PSPs (4 in unlogged forests) in low altitude forests on uplands $(H)$.

\section{Data analysis}

\section{Tree taxonomic composition}

Selective-harvesting in PNG affects forest structure with respect to basal area (BA), timber volume and number of stems (Yosi et al. 2011). Our aim was to determine whether logging activities had an impact on tree species composition, focusing on both commercial and non-commercial species (Eddowes 1977, PNGFA 1996). To this end, we compared the taxonomic composition of unlogged and logged-over (0-4 YAL) PSPs using multivariate analysis techniques. PRIMER6 version 6.1.14 and PERMANOVA+ version 1.0.6 analysis software (Clarke \& Gorley 2006) was used for ordination analyses of tree taxonomic composition. Abundance data was square-root transformed to downweight the importance of the highly abundant species (Clarke \& Warwick 2001).

We used canonical analyses of principal coordinates (CAP) ordination method (Anderson \& Willis 2003) with the Bray-Curtis dissimilarity metric (Bray \& Curtis 1957), and permutation multivariate analysis of variance (PERMANOVA - Anderson 2001) and PERMDISP (Anderson 2006) to test for differences in statistical location and dispersion, respectively, among VTs and logging regimes. Significant differences in dispersion between groups of different logging regimes within a VT would put some constraints in the interpretation of significant PERMANOVA results. For all the tests we set 9999 permutations. The correlation of tree species (after transformation) with the CAP axes was calculated to determine which taxa were responsible for the tested differences. We chose the Pearson correlation coefficient considering only species with an absolute correlation $>0.3$ and tested for significant differences between mean abundances of the identified species

Tab. 1 - Results of PERMANOVA test for differences in tree taxa composition between PSP of different vegetation types (VT) and logging regime (LOG), pair-wise comparison between levels of factor LOG and PERMDISP test for difference in dispersion. $(P)$ : Lowland forests on plains and fans; $(H)$ : lowland forests on uplands; $(*): p<0.05 ;(* *)$ : $\mathrm{p}<0.01 ;(* * *) ; \mathrm{p}<0.001 ;$ (ns): not significant.

\begin{tabular}{|c|c|c|c|c|c|c|c|}
\hline \multicolumn{3}{|c|}{ PERMANOVA } & \multicolumn{2}{|c|}{$\begin{array}{l}\text { Pair-wise Comparisons } \\
\text { (between LOG levels) }\end{array}$} & \multicolumn{2}{|c|}{$\begin{array}{l}\text { Dispersion within groups } \\
\text { (Mean } \pm \text { SD) }\end{array}$} & \multirow{2}{*}{ 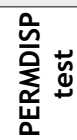 } \\
\hline Factors & Pseudo-F & VT & $t$ & Perms & Logged & Unlogged & \\
\hline VT & 1.72 * & $P$ & $1.17^{\text {ns }}$ & 9869 & $43.28 \pm 1.16$ & $36.41 \pm 2.27$ & 2.13 \\
\hline LOG & 1.76 * & $\mathrm{H}$ & 1.29 * & 9512 & $42.92 \pm 1.39$ & $39.14 \pm 2.70$ & 0.83 \\
\hline
\end{tabular}

in different groups using a non-parametric Wilcoxon-Mann-Whitney test. Finally, we identified the life history strategies (LHS) of such species (Damas K.Q., personal communication).

\section{Diversity and structure indexes}

To examine the effects of logging on forest diversity, we estimated Shannon's diversity index (Shannon 1948) and Pielou's evenness measure (Pielou 1966) for each plot. The former was calculated as (eqn. 1):

$$
H^{\prime}=-\sum_{i=1}^{S} p_{i} \ln p_{i}
$$

where $p_{\mathrm{i}}$ is the proportion of individuals belonging to the $i$-th species. The Pielou's index is expressed as (eqn. 2):

$$
J=\frac{H^{\prime}}{\ln (S)}
$$

where $S$ is the total number of taxa. Additionally, we calculated the total BA and the number of stems for each plot as a measure of tree cover and density.

Differences in richness, diversity, evenness, total BA and stem density between unlogged and logged-over forests (0-4 YAL) within the two VTs were tested with two-way ANOVAs on the first census of the PSPs. Pair-wise Student's t-tests were carried out when appropriate. To observe trends of the aforementioned indexes with elapsed YAL in both VTs, we fitted five multiple linear regression models. The calcula- tions were carried out using the $\mathrm{R}$ software.

\section{Results}

\section{Tree taxonomic composition}

Significant differences in taxonomic composition were found between the two VTs (Pseudo-F $=1.72 ; p=0.01$ ) and between logged-over and unlogged forests (Pseudo$F=1.76 ; p=0.01$ ) which, however, were ascribable only to differences between logged-over and unlogged forests of the $\mathrm{H}$ type $(t=1.29 ; p=0.04-$ Tab. 1$)$. No constraints to the interpretation of PERMANOVA results were detected, as dispersions among the tested groups were homogeneous (Tab. 1).

CAP ordination discerned between plots of different VTs and disturbance regimes. However, while logged-over plots are well differentiated from unlogged plots of the type $\mathrm{H}$ along axis 2, weaker differences were found between logged-over and unlogged plots of the type $P$, consistently with PERMANOVA (Fig. 2). The taxa which are responsible for the identified differences within VT H were identified according to their correlation with CAP axis 2. Tab. 2 reports all the taxa with significant differences in abundance between logged-over and unlogged forests of the type $\mathrm{H}$, along with their Pearson's correlation coefficient and LHS codes. All the taxa showed negative correlation with CAP axis 2, meaning

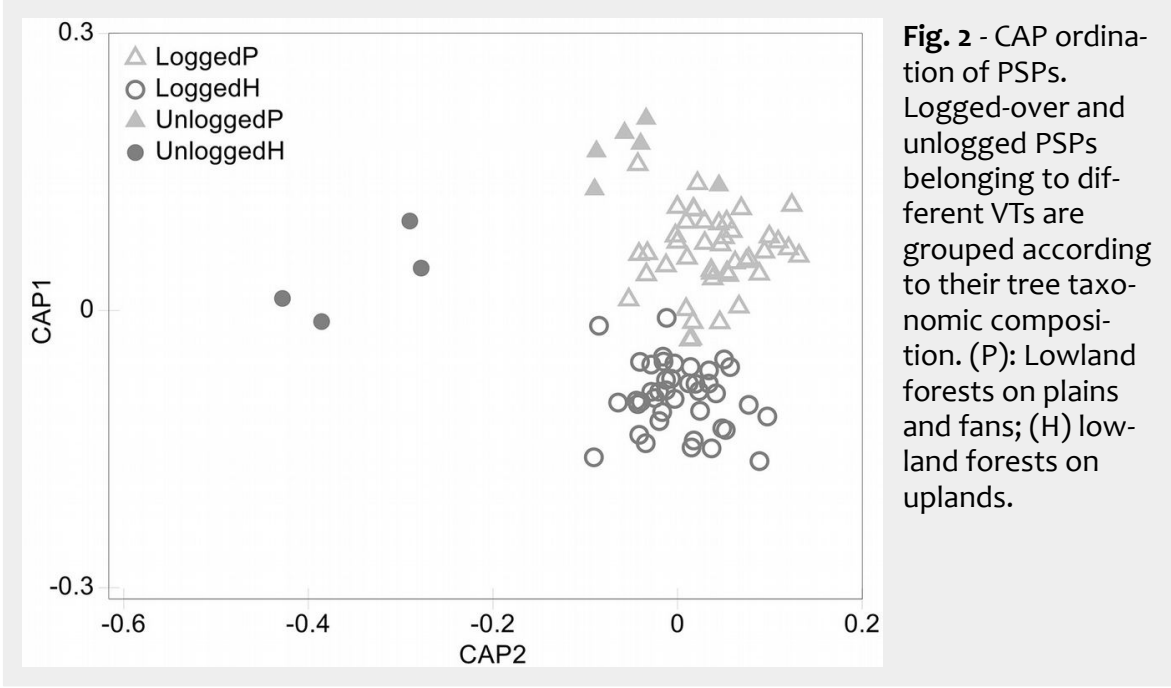


Tab. 2 - Pearson's correlation coefficients of species with CAP axis 2. Average abundances and SDs are reported for logged-over and unlogged forest plot of the $\mathrm{H}$ type. (c): commercial species. (LHS): Life History Strategy codes; (SS) short lived secondary species; (LS): long lived secondary species; $(P)$ : primary species. $\left({ }^{*}\right): p<0.05 ;\left({ }^{* *}\right): p<$ $0.01 ;(* *) ; p<0.001 ;(n s)$ : not significant.

\begin{tabular}{|c|c|c|c|c|c|}
\hline Taxon & Correlation & $\begin{array}{c}\text { Logged } \\
(\text { stems 100ha-1) }\end{array}$ & $\begin{array}{c}\text { Unlogged } \\
(\text { stems 100ha-1) }\end{array}$ & W & LHS \\
\hline Alstonia scholaris ${ }^{c}$ & -0.35 & $39 \pm 97$ & $475 \pm 754$ & $33.5^{*}$ & LS \\
\hline Calophyllum europhyllum ${ }^{c}$ & -0.64 & $39 \pm 174$ & $1900 \pm 2248$ & $43.0 * *$ & LS \\
\hline Dillenia papuana ${ }^{c}$ & -0.56 & $110 \pm 526$ & $1325 \pm 1552$ & $24.5^{* * *}$ & $P$ \\
\hline Drypetes spp ${ }^{c}$ & & & $100 \pm$ & $42.5^{* * *}$ & $P$ \\
\hline Euphorbia spp. & -0.35 & $2 \pm 16$ & $75 \pm 96$ & $42.5^{* * *}$ & SS \\
\hline Litsea firma ${ }^{\mathrm{c}}$ & -0.51 & $32 \pm 133$ & $850 \pm 995$ & $44.0 * *$ & $P$ \\
\hline Myristica subalulata ${ }^{\mathrm{c}}$ & -0.62 & $78 \pm 339$ & $2700 \pm 3156$ & $120.0 * *$ & $P$ \\
\hline Rhizophora spp. ${ }^{c}$ & -0.48 & $5 \pm 22$ & $50 \pm 58$ & $45.0 * *$ & $P$ \\
\hline Symplocos spp. & -0.58 & $7 \pm$ & $250 \pm 332$ & $44.0 * *$ & $P$ \\
\hline Xylopia spp. ${ }^{c}$ & -0.36 & $54 \pm 182$ & $275 \pm 189$ & $30.0 * *$ & LS \\
\hline
\end{tabular}

that they were less abundant in loggedover forests (with Calophyllum europhyllum, Dillenia papuana, Litsea firma and Myristica subalulata showing the strongest correlation to the axis 2), the majority of which belonged to the primary species group.

\section{Diversity and structure indexes}

Greater taxonomic richness $(p=0.02)$ and stem density $(p=0.001)$ were found in $\mathrm{P}$ type forests $\left(58 \pm 13\right.$ taxa ha ${ }^{-1} ; 355 \pm 137$ stems ha ${ }^{-1}$ ) compared to $\mathrm{H}$ type ones (52 \pm 12 taxa ha-1; $281 \pm 81$ stems ha $\left.{ }^{-1}\right)$. As for richness, diversity $\left(H^{\prime}\right)$ and evenness $(J)$, no significant differences were discovered between logged-over and unlogged forest plots, while we found higher stem density

Tab. 3 - Results of the two-way ANOVA for genus richness, diversity $\left(H^{\prime}\right)$, evenness $(J)$, stem density and BA between $\mathrm{H}$ and $\mathrm{P}$ vegetation types (VT), and logged-over and unlogged (LOG) plots. Separate $t$-tests were carried out for BA. Means and SDs of the parameters are provided. $(P)$ : Lowland forests on plains and fans; $(H)$ : Lowland forests on uplands; $(*): p<0.05 ;(* *): p<0.01$; $(* * *) ; \mathrm{p}<0.001 ;(\mathrm{ns})$ : not significant.

\begin{tabular}{|c|c|c|c|c|c|c|c|}
\hline Statistics & Factors/Type & $\begin{array}{l}\text { Richness } \\
\left(\text { taxa ha }^{-1}\right)\end{array}$ & $\begin{array}{l}\text { Diversity } \\
\left(H^{\prime}\right)\end{array}$ & $\begin{array}{l}\text { Evenness } \\
(J)\end{array}$ & $\begin{array}{l}\text { Stem density } \\
\left(\text { stems ha }^{-1}\right)\end{array}$ & $\begin{array}{l}\text { BA } \\
\left(m^{2} h a^{-1}\right)\end{array}$ & \\
\hline \multirow[t]{3}{*}{ ANOVA $F$} & VT & $5.50 *$ & $2.40^{\mathrm{ns}}$ & $0.06^{\mathrm{ns}}$ & 10.81 ** & & $2.47^{\mathrm{ns}}$ \\
\hline & LOG & $0.47^{\mathrm{ns}}$ & $0.12^{\mathrm{ns}}$ & $0.04^{\mathrm{ns}}$ & $8.56^{* *}$ & & $31.46^{* * *}$ \\
\hline & VT $\times$ LOG & $0.20^{\text {ns }}$ & $0.43^{\mathrm{ns}}$ & $0.78^{\mathrm{ns}}$ & $1.27^{\mathrm{ns}}$ & & $13.87^{* * *}$ \\
\hline \multirow[t]{4}{*}{ Means \pm SD } & Logged & $54.45 \pm 12.66$ & $3.39 \pm 0.31$ & $0.85 \pm 0.04$ & $307.62 \pm 109.64$ & Type P & $17.80 \pm 4.18$ \\
\hline & & & & & & $\begin{array}{l}\text { Type H } \\
t\end{array}$ & $\begin{array}{l}15.52 \pm 4.04 \\
\text { ns }\end{array}$ \\
\hline & Unlogged & $57.80 \pm 11.93$ & $3.43 \pm 0.21$ & $0.85 \pm 0.03$ & $421.10 \pm 153.30$ & Type P & $21.48 \pm 7.33$ \\
\hline & & & & & & $\begin{array}{l}\text { Type } \mathrm{H} \\
t\end{array}$ & $\underset{* *}{30.28 \pm 4.45}$ \\
\hline
\end{tabular}

Tab. 4 - Outputs of the multiple linear regression models for five stand features. Factors considered are vegetation type (VT) and years after logging $(\mathrm{YAL})$. Coefficients values $( \pm \mathrm{SE})$ and their significance are provided. Adjusted $\mathrm{R}^{2}$ values and significance of the models are reported. $(*): p<0.05 ;(* *): p<0.01 ;(* *) ; p<0.001 ;(n s)$ : not significant.

\begin{tabular}{|c|c|c|c|c|c|c|c|}
\hline \multirow{3}{*}{$\begin{array}{l}\text { Variable } \\
\text { Richness (taxa ha }{ }^{-1} \text { ) }\end{array}$} & Adj. $R^{2}$ & $\mathrm{~F}$ & Parameter & Intercept & VT & YAL & $\mathrm{VT} \times \mathrm{YAL}$ \\
\hline & 0.036 & $5.05^{* *}$ & Coeff. & $53.73 \pm 1.41$ & $3.69 \pm 2.10$ & $0.55 \pm 0.19$ & $-0.18 \pm 0.29$ \\
\hline & & & $t$ & $38.12^{* * *}$ & $2.98^{\text {ns }}$ & $1.76^{* *}$ & $-0.63^{\text {ns }}$ \\
\hline Diversity (H') & 0.033 & $4.60 * *$ & $\begin{array}{l}\text { Coeff. } \\
t\end{array}$ & $\begin{array}{l}3.33 \pm 0.03 \\
106.09 * * *\end{array}$ & $\begin{array}{l}0.10 \pm 0.004 \\
2.65 *\end{array}$ & $\begin{array}{l}0.01 \pm 0.05 \\
2.21^{* *}\end{array}$ & $\begin{array}{l}-0.01 \pm 0.01 \\
-0.83^{\mathrm{ns}}\end{array}$ \\
\hline Evenness $(\mathrm{J})$ & 0.006 & $1.67^{* * *}$ & $\begin{array}{l}\text { Coeff. } \\
t\end{array}$ & $\begin{array}{l}0.84 \pm 0.004 \\
193.20^{* * *}\end{array}$ & $\begin{array}{l}0.01 \pm 0.001 \\
0.77^{\text {ns }}\end{array}$ & $\begin{array}{l}0.0004 \pm 0.01 \\
1.80^{\text {ns }}\end{array}$ & $\begin{array}{l}0.0004 \pm 0.001 \\
-0.54^{\text {ns }}\end{array}$ \\
\hline Stem Density (stems ha ${ }^{-1}$ ) & 0.127 & $16.53^{* * *}$ & $\begin{array}{l}\text { Coeff. } \\
t\end{array}$ & $\begin{array}{l}280.06 \pm 10.45 \\
26.79^{* * *}\end{array}$ & $\begin{array}{l}73.40 \pm 15.58 \\
4.71^{* * *}\end{array}$ & $\begin{array}{l}8.98 \pm 1.38 \\
6.51^{* * *}\end{array}$ & $\begin{array}{l}-8.27 \pm 2.15 \\
-3.84^{* * *}\end{array}$ \\
\hline Basal area $\left(\mathrm{m}^{2} \mathrm{ha}^{-1}\right)$ & 0.134 & $17.58^{\text {ns }}$ & $\begin{array}{l}\text { Coeff. } \\
t\end{array}$ & $\begin{array}{l}14.71 \pm 0.48 \\
30.44^{* * *}\end{array}$ & $\begin{array}{l}3.14 \pm 0.72 \\
4.36^{* * *}\end{array}$ & $\begin{array}{l}0.42 \pm 0.06 \\
6.53^{* * *}\end{array}$ & $\begin{array}{l}-0.31 \pm 0.10 \\
-3.17^{* *}\end{array}$ \\
\hline
\end{tabular}

Tab. 5 - Outputs of the linear regression models for stem density and basal area with years after logging (YAL) in two vegetation types $(\mathrm{P}$ and $\mathrm{H})$. Coefficients values $( \pm \mathrm{SE})$ and their significance are provided. Adjusted $\mathrm{R}^{2}$ values and significance of the models are reported. (P): Lowland forests on plains and fans; $(H)$ : Lowland forests on uplands; $(*): p<0.05 ;(* *): p<0.01 ;(* * *) ; p<0.001 ;(n s)$ : not significant.

\begin{tabular}{|c|c|c|c|c|c|c|}
\hline $\begin{array}{l}\text { Vegetation } \\
\text { Type }\end{array}$ & Variable & Adj. $R^{2}$ & $\mathbf{F}$ & Parameter & Intercept & YAL \\
\hline \multirow[t]{2}{*}{$P$} & Stem density (stems ha $\left.{ }^{-1}\right)$ & 0.005782 & 0.1262 & $\begin{array}{l}\text { Coeff. } \\
t\end{array}$ & $\begin{array}{l}353.46 \pm 14.07 \\
25.13^{* * *}\end{array}$ & $\begin{array}{l}0.71 \pm 2.01 \\
0.36^{\text {ns }}\end{array}$ \\
\hline & Basal area $\left(\mathrm{m}^{2} \mathrm{ha}^{-1}\right)$ & 0.004483 & 1684.0 & $\begin{array}{l}\text { Coeff. } \\
t\end{array}$ & $\begin{array}{l}17.85 \pm 0.55 \\
32.45^{* * *}\end{array}$ & $\begin{array}{l}0.10 \pm 0.08 \\
1.30^{\mathrm{ns}}\end{array}$ \\
\hline \multirow[t]{2}{*}{$\mathrm{H}$} & Stem density (stems ha $\left.{ }^{-1}\right)$ & 0.3067 & $75.32^{* * *}$ & $\begin{array}{l}\text { Coeff. } \\
t\end{array}$ & $\begin{array}{c}280.06 \pm 7.84 \\
35.73 * * *\end{array}$ & $\begin{array}{l}8.98 \pm 1.04 \\
8.68^{* * *}\end{array}$ \\
\hline & Basal area $\left(\mathrm{m}^{2} \mathrm{ha}^{-1}\right)$ & 0.2084 & $45.23^{* * *}$ & $\begin{array}{l}\text { Coeff. } \\
t\end{array}$ & $\begin{array}{l}14.71 \pm 0.47 \\
31.33^{* * *}\end{array}$ & $\begin{array}{l}0.42 \pm 0.06 \\
6.73 * * *\end{array}$ \\
\hline
\end{tabular}


Fig. 3 - Scatter plots showing trends in stand features. The graphs reports 322 censuses of 91 logged-over PSPs' belonging to two different vegetation types: $\mathrm{H}$ (black) and P (grey). Linear regression lines are shown. Richness (a) and

Shannon diversity (b) showed significant increase in both vegetation types. Stem density (d) and BA (e), increased only in $\mathrm{H}$ type forests. Evenness (c) showed no significant change with years after logging.
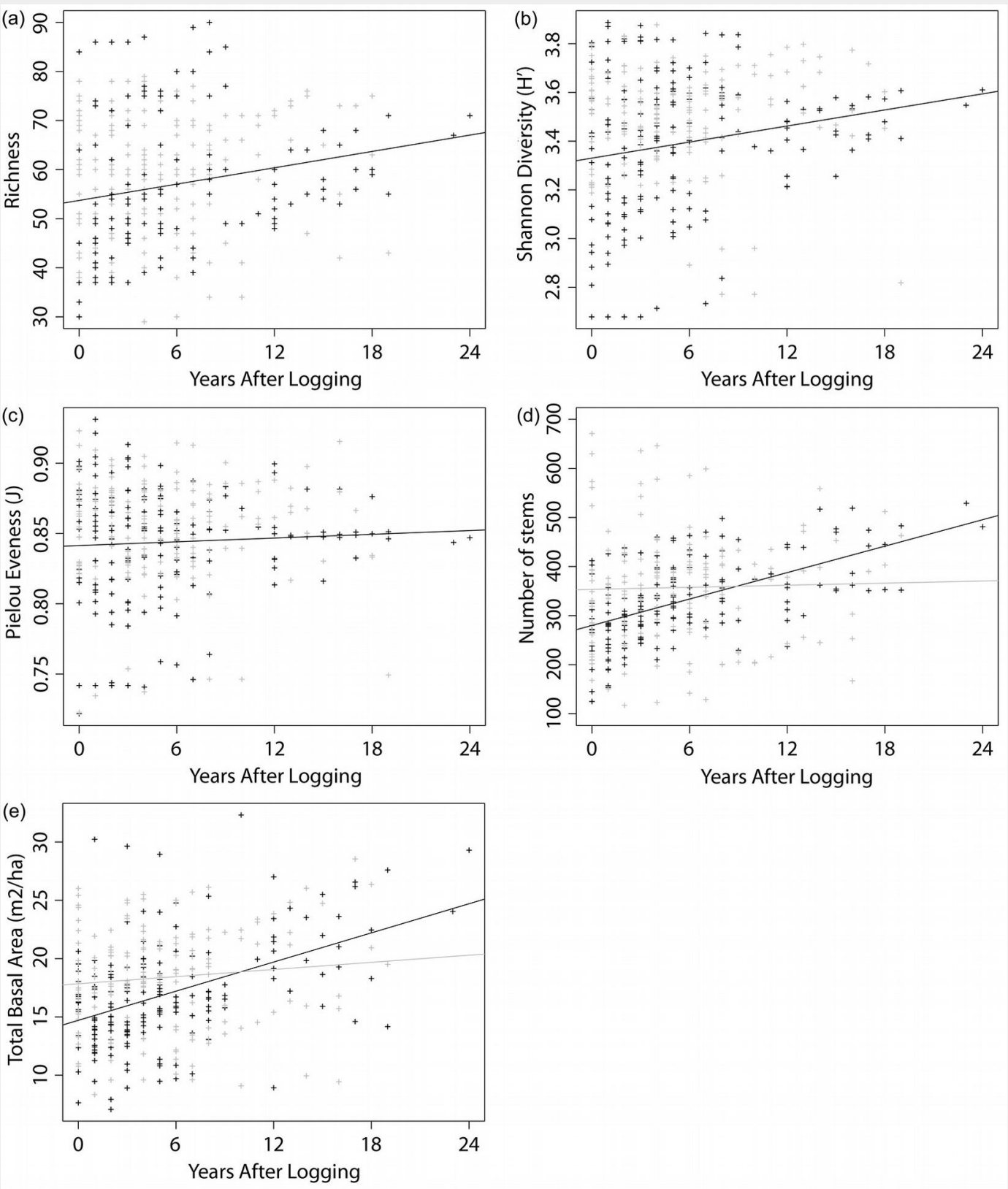

in unlogged PSPs $\left(421 \pm 153\right.$ stems ha $\left.{ }^{-1}\right)$ than in logged-over ones $\left(308 \pm 110\right.$ stems ha $\left.{ }^{-1}\right)$. Regarding the $\mathrm{BA}$, the interaction factor in ANOVA between logging regime and VT was significant $(p=0.0003)$. Hence, we analyzed the former separately for the two VTs and found significant differences between logged-over and unlogged plots of the $\mathrm{H}$ type forests $(p=0.005-$ Tab. 3$)$.

Furthermore, we examined the trends in the considered indexes in relation to the YAL, accounting for different VTs. The outputs of the multiple linear regression models are reported in Tab. 4. The analysis of richness trend with elapsed YAL highlighted a slight increase in the number of taxa (Fig. 3a), with a gain of about one new taxon per hectare every two years. Similarly, diversity showed some increase with time (Fig. 3b), while evenness remained roughly constant through the years (Fig. 3c). The interaction factor $(V T \times Y A L)$ of the linear model was found significant for stem density and BA (Tab. 4), thus we built separate linear models to analyze their trends with YAL for the two VTs (Tab. 5). No significant trend in relation to the YAL was detected for stem density and BA in $\mathrm{P}$ type forests, while $\mathrm{H}$ type forests showed a gain of $9 \pm 1$ stems ha ${ }^{-1} \mathrm{yr}^{-1}$ and $0.42 \pm 0.06 \mathrm{~m}^{2} \mathrm{ha}^{-1}$ $\mathrm{yr}^{-1}$ (Fig. 3d, Fig. 3e).

\section{Discussion}

Our analyses revealed significant differences in tree taxonomic composition between VTs and between logged-over and unlogged forests of the $\mathrm{H}$ type (Tab. 1). CAP ordination provided a meaningful graphical representation of these results (Fig. 2). Plots belonging to different VTs were grouped separately along axis 1 , despite being very close to each other. Indeed, they shared some of the most common species that are present in PNG lowland forests, such as Pometia pinnata, and Pimeleodendron amboinicum and several common genera like Syzigium spp. and Cananga spp. (which together account for more than $50 \%$ of all the identified taxa). Conversely, some species were only present in $\mathrm{H}$ type plots (e.g., Calophyllum europhyllum, Gmelina dalrympleana, Decaspermum fruiticosum and Timonius pulposus) while others were found only in plots of the P type (e.g., Gulubia costata, Hopea papuana, Tetrameles nudiflora and Trichospermum burretii). Thus, their subtle differences could be attributed to the relative abundance of the most common taxa and to the composition of the rarest. This is coherent with PNG's elevation-zone based vegetation classification by Hammermaster \& Saunders (1995), which places all forests between 0 and $1000 \mathrm{~m}$ a.s.l. in the same class. An explanation to this could be that, given the narrow altitudinal range, differences in tree species composition of the two lowland forests might rather be related to soil conditions and water drainage 
(Paijmans 1975), even though further studies are required to test this hypothesis. When looking at taxonomic composition of $\mathrm{H}$ type forests, logged-over and unlogged ones are clearly differentiated (Fig. 2 and Tab. 2). In particular, most of the taxa showing the highest absolute correlation with CAP axis 2 belong to the commercial group and include Calophyllum europhyllum, Dillenia papuana, Litsea firma, Myristica subalulata and Rhizophora spp. This indicates lower abundance of these taxa in logged-over plots, which could be ascribed to commercial harvesting activities. Even some non-commercial taxa, such as Euphorbia spp. and Symplocos spp., were less abundant in logged-over forest plots, suggesting that logging activities affect their abundance as in the case for commercial ones. These effects could be explained by the relatively low selectivity of logging practices that are usually carried out in PNG. Accidental damages during felling of other trees or skidding and construction of logging roads are frequent (Cameron \& Vigus 1992, Verissimo et al. 1992, Abe et al. 1999, Nepstad et al. 1999, Shearman et al. 2008) and have a significant impact on all tree species, regardless of their commercial value. Indeed, when $21 \%$ of stems were harvested in Bulolo, in the Morobe Province of PNG, only $17 \%$ of them remained after the logging operation (Enright 1978). Predictably, a higher abundance of primary taxa (such as Dillenia papuana, Litsea firma and Myristica subalulata) in unlogged forests emerged from the correlation analysis, even though some secondary taxa (Alstonia scholaris, Calophyllum europhyllum, Euphorbia spp., Xylopia spp.) have also shown high correlation with CAP axis 2 . This could be explained by taking into account natural (e.g., fire or drought) and anthropogenic disturbance, as the majority of plots was established close to roads in order to facilitate re-measurement. Therefore, human-induced disturbances might have affected even the unlogged plots, favoring the growth of such species. Differently from what observed on type $\mathrm{H}$, no significant differences were detected between logged-over and unlogged forests of the type $\mathrm{P}$. However, even unlogged $\mathrm{P}$ forests were characterized by greater abundance of both commercial (e.g., Cananga spp., Hibiscus spp., Sterculia spp.) and non-commercial genera (e.g., Gonocaryum spp., Haplolobos spp., Tristania spp.) and were slightly isolated by CAP ordination (Fig. 2).

Unlogged PSPs seemed to exhibit slightly greater average taxonomic richness and diversity than logged-over plots, although the difference was not statistically significant (Tab. 3). This is consistent with several previous studies, which have reported that the species diversity of logged-over tropical forest was not significantly different from adjacent, undisturbed forest within a relatively short period after logging (e.g., $<20$ years - Pelissier et al. 1998, Hall et al.
2003, Verburg \& Van Eijk-Bos 2003, Bischoff et al. 2005). Nevertheless, we believe that our unlogged plots were probably too few to provide a reliable evaluation of the tree richness and diversity which, due to the high variability and heterogeneity of tropical forests, could have been under-estimated.

Earlier studies indicated that BA in PNG primary forests could reach about $30-33 \mathrm{~m}^{2}$ ha ${ }^{-1}$ and drop to values as low as $10 \mathrm{~m}^{2} \mathrm{ha}^{-1}$ in case of high intensity logging (Oavika 1992, Alder 1998, Kingston \& Nir 1998). The results we obtained for $\mathrm{H}$ type forests are in line with these figures, with BA exhibiting higher values in unlogged PSPs (30.28 $\pm 4.45 \mathrm{~m}^{2} \mathrm{ha}^{-1}$ ) compared to logged-over plots $\left(15.52 \pm 4.04 \mathrm{~m}^{2}\right.$ ha-1). This result witnesses the remarkable level of harvesting in some PNG lowland forests and is very close to the $15 \mathrm{~m}^{2}$ ha-1 reported by Keenan et al. (2005). Again, forests plots of the $P$ type did not show any difference in this regard, probably because unlogged forests on plains and fans - with only $21.48 \pm 7.33$ $\mathrm{m}^{2} \mathrm{ha}^{-1}$ - were exposed to some kind of perturbation. This may also explain why no difference was detected between the taxonomic composition of unlogged and logged-over PSPs belonging to the $\mathrm{P}$ type. Additionally, stem density was significantly greater in unlogged forests $(421 \pm 153$ stems ha ${ }^{-1}$ ) compared to logged-over ones $\left(308 \pm 110\right.$ stems ha $\left.^{-1}\right)$ in both VTs.

When looking at trends, both BA and stem density in $\mathrm{H}$ type forests significantly increase with YAL $(p<0.0001$ - Fig. 3d, Fig. $3 e$ ) and reach, after 24 years, values that are comparable to those of unlogged forests $\left(29.30 \mathrm{~m}^{2} \mathrm{ha}^{-1}\right.$ and 481 stems ha-1). This result corroborates the findings of Ferry Slik et al. (2002), who analyzed recovery processes after logging in the tropical forests of Indonesia. On the other hand, $\mathrm{P}$ type forests did not exhibit any significant trend. Diversity indexes revealed differential patterns of change in relation to the YAL. While richness and diversity showed slightly positive trends with elapsed YAL (Fig. 3a, Fig. 3b), evenness remained roughly constant through time. One possible explanation is that new taxa recorded in the plots were represented by very few individuals, thus leading to an increase in richness and diversity only. Moreover, as the available dataset included only trees $>10 \mathrm{~cm} \mathrm{DBH}$, our analyses did not account for short-lived pioneer species, or species only present as saplings and seedlings, which could strongly influence species evenness, richness and compositional dynamics in the years following timber harvesting.

\section{Conclusions}

Our analysis highlighted some significant effects of logging activities on tree biodiversity and structure of PNG forests, although showing contrasting results. These spatio-temporal patterns could be further clarified with an improved sample design, as well as with before-after control-impact (BACl) studies (Lindenmayer 1999) with different intensities of timber harvesting. Additionally, the number of unlogged forest plots should be increased to obtain a precise assessment of the impact of logging in PNG forests, and consecutive censuses should be carried out in both loggedover and unlogged plots at the same time, in order to allow for meaningful monitoring of forest dynamics following disturbance. However, our results provided some important preliminary insights on the topic and will be useful when compared with those that will be acquired with the new NFI, which is being developed under the arrangements for REDD+. This will be instrumental in assessing and monitoring the impact of human activities and ecological factors on PNG forest biodiversity, and will support the development of sound strategies for the conservation and sustainable management of the nation's biodiverse forest heritage.

\section{Acknowledgements}

RT, GG and FA conceived the study. AF and RT performed the statistical analyses. $\mathrm{CY}$, SS and MDS helped to draft the manuscript.

This study was supported by FAO Mountain Partnership Secretariat and the Italian Development Cooperation (DCGS).

\section{References}

Abe H, Sam N, Niangu M, Vatnabar P, Kiyono $Y$ (1999). Effect of logging on forest structure at the Mongi-Busiga forest research plots: Finschafen, Papua New Guinea. In: Proceedings of the "PNGFRI-JICA international forestry seminar”. Lae (Papua New Guinea) 4-7 October 1999. PNGFRI, Lae, Papua New Guinea, pp. 157. Alder D (1998). PINFORM: A growth model for lowland tropical forest in Papua new Guinea. ITTO Project PD162-91/PNGFRI, PNG Forest Research Institute, Lae, Papua New Guinea, pp. 49.

Alder D, Synnott TJ (1992). Permanent sample plot techniques for mixed tropical forest. Oxford Forestry Institute, University of Oxford, Oxford, UK, pp. 124.

Alder D, Oavika F, Yosi CK (1999). Data, programs and models for natural forest growth and yield. ITTO Project PD 162/91-PNGFRI, Lae, Papua New Guinea, pp. 37.

Anderson MJ (2001). Permutation tests for univariate or multivariate analysis of variance and regression. Canadian Journal of Fisheries and Aquatic Sciences 58: 626-639. - doi: 10.1139/fo1004

Anderson MJ (2006). Distance-based tests for homogeneity of multivariate dispersions. Biometrics 62: 245-253. - doi: 10.1111/j.1541-0420.20 05.00440.x

Anderson MJ, Willis TJ (2003). Canonical analysis of principal coordinates: a useful method of constrained ordination for ecology. Ecology 84 (2): 511-525. - doi: 10.1890/0012-9658(2003)084 [0511:CAOPCA]2.0.CO;2

APAG (1990). The Barnett report. A summary of the report of the commission of inquiry into 
aspects of the timber industry in Papua New Guinea. The Asian Pacific Action Group, Hobart, Australia, pp. 59.

Barlow J, Gardner TA, Araujo IS, Ávila-Pires TC, Bonaldo AB, Costa JE, Esposito MC, Ferreira LV, Hawes J, Hernandez MIM, Hoogmoed MS, Leite RN, Lo-Man-Hung NF, Malcolm JR, Martins MB, Mestre LAM, Miranda-Santos R, Nunes-Gutjahr AL, Overal WR, Parry L, Peters SL, Ribeiro-Junior MA, Da Silva MNF, Da Silva Motta C \& Peres CA (2007). Quantifying the biodiversity value of tropical primary, secondary, and plantation forests. Proceedings of the National Academy of Science USA 104: 18555-18560. - doi: 10.1073/pnas.0703333104 Barr J (1999). Drought assessment: the 1997-98 El Niño drought in Papua New Guinea and the Solomon Islands. Australian Journal of Emergency Management 1999: 35-41. [online] URL: http://www.pacificdisaster.net/pdnadmin/data/ original/PNG_SLB_ELNino_1997_98_drought_a ssesment.pdf

Bellamy JA, McAlpine JR (1995). Papua New Guinea inventory of natural resources, population distribution and land use handbook ( $2^{\text {nd }}$ edn). Australian Agency for International Development, Camberra, Australia, pp. 149.

Bicknell JE, Struebig MJ, Davies ZG (2015). Reconciling timber extraction with biodiversity conservation in tropical forests using reducedimpact logging. Journal of Applied Ecology 52: 379-388. - doi: 10.1111/1365-2664.12391

Bischoff W, Newbery DM, Lingenfelder $M$, Schnaeckel R, Petol GH, Madani L, Ridsdale CE (2005). Secondary succession and dipterocarp recruitment in Bornean rainforest after logging. Forest Ecology and Management 218: 174192. - doi: 10.1016/j.foreco.2005.07.009

Borden W, Ward G (2006). Country environmental profile: Papua New Guinea - Final Report. Framework Contract AMS/451 Lot No. 6. Request for Services $N^{\circ} 2005 / 102581$. European Commission and Government of Papua New Guinea, Port Moresby, Papua New Guinea, pp. 72.

Bray JR, Curtis JT (1957). An ordination for the upland forest communities in southern Wisconsin. Ecological Monographs 27: 325-349. - doi: $10.2307 / 1942268$

Brooks TM, Mittermeier RA, Fonseca GAB, Gerlach J, Hoffmann M, Lamoreux JF, Mittermeier CG, Pilgrim JD, Rodrigues ASL (2006). Global biodiversity conservation priorities. Science 313: 58-61. - doi: 10.1126/science.1127609

Bryant D, Nielsen D, Tangley L (1997). The last frontier forests: ecosystems and economies on the edge. World Resource Institute. Washington DC, USA, pp. 54.

Cameron AL, Vigus TR (1992). Regeneration and growth of the moist tropical forest in Papua New Guinea and the implications for future harvest. Commonwealth Scientific and industrial Research Organization, Division of Wildlife and Ecology, Canberra, Australia, pp. 15.

Clarke KR, Gorley RN (2006). PRIMER v6: user manual/tutorial. PRIMER-E, Plymouth, UK, pp. 190.

Clarke KR, Warwick RM (2001). Change in marine communities: an approach to statistical analysis and interpretation ( $2^{\text {nd }}$ edn). PRIMER-E Ltd, Plymouth, UK, pp. 176.
Davis SD, Heywood VH, Hamilton AC (1995). Centres of plant diversity: vol 2. Asia, Australia and the Pacific. WWF/IUCN, Gland, Switzerland, pp. 592.

Eddowes PJ (1977). The utilization of Papua New Guinea Timbers. Department of Primary Industry, Office of Forests, Forest Products Research Centre, Port Moresby, Papua New Guinea, pp. 28.

Edwards DP, Larsen TH, Docherty TDS, Ansell FA, Hsu WW, Derhè MA, Hamer KC, Wilcove DS (2011). Degraded lands worth protecting: the biological importance of Southeast Asia's repeatedly logged forests. Proceedings of the Royal Society B 278: 82-90. - doi: 10.1098/rspb. 2010.1062

Edwards DP, Tobias JA, Sheil D, Meijaard E, Laurance WG (2014). Maintaining ecosystem function and services in logged tropical forests. Trends in Ecology and Evolution 29: 511-520. doi: 10.1016/j.tree.2014.07.003

Enright NJ (1978). The effects of logging on the regeneration and nutrient budget of Araucaria cunninghamii dominated tropical rainforest in Papua New Guinea. The Malaysian Forester 41: 303-318.

Ferry Slik JW, Verburg RW, Keßler PJA (2002). Effect of fire and selective logging on tree species composition of lowland dipterocarp forest of East Kalimantan, Indonesia. Biodiversity and Conservation 11: 85-98. - doi: 10.1023/A:1014 036129075

Filer C, Sekhran N (1998). Loggers, donors and resource owners. Policy that works for forests and people series no. 2: Papua New Guinea. International Institute for Environment and Development, London, UK, pp. 416. [online] URL: http://books.google.com/books?id=nBv_uMOH bZoC

Filer C, Keenan RJ, Allen BJ, McAlpine JR (2009). Deforestation and forest degradation in Papua New Guinea. Annals of Forest Science 66: 813825. - doi: $10.1051 /$ forest/2009067

Fox JC, Keenan RJ (2010). Final report. Assessment, management and marketing of goods and services from cutover native forests in Papua New Guinea. ACIAR, Canberra, Australia, pp. 44.

Fox JC, Yosi CK, Keenan RJ (2011a). Forest carbon and REDD+ in Papua New Guinea. In: "Native forest management in Papua New Guinea: advances in assessment, modelling and decision-making" (Fox JC, Keenan RJ, Brack CL and Saulei S eds). ACIAR Proceedings 135: 3240.

Fox JC, Yosi CK, Nimiago P, Oavika F, Pokana JN, Lavong K, Keenan RJ (2010). Assessment of aboveground carbon in primary and selectively harvested tropical forest in Papua New Guinea. Biotropica 42 (4): 410-419. - doi: 10.1111/j.17447429.2009.00617.x

Fox JC, Vieilledent G, Yosi CK, Pokana JN, Keenan RJ (2011b). Aboveground forest carbon dynamics in Papua New Guinea: isolating the influence of selective harvesting and El-Niño. Ecosystems 14 (8): 1276-1288. - doi: 10.1007/s 10021-011-9480-4

Grussu G, Attorre F, Mollicone D, Dargush P, Guillet A, Marchetti M (2014). Implementing REDD+ in Papua New Guinea: can biodiversity indicators be effectively integrated in PNG's
National Forest Inventory? Plant Biosystems 148 (3): 519-528. - doi: 10.1080/11263504.2014.90 0131

Hall JS, Harris DJ, Medjibe V, Ashton PMS (2003). The effects of selective logging on forest structure and tree species composition in a Central African forest: implications for management of conservation areas. Forest Ecology and Management 183: 249-264. - doi: 10.1016/S0378-1127 (03)00107-5

Hammermaster ET, Saunders JC (1995). Forest resources and vegetation mapping of Papua New Guinea. CSIRO, Canberra, Australia, pp. 249.

Howard PC, Viskanic P, Davenport TRB, Kigenyi FW, Baltzer M, Dickinson CJ, Lwanga JS, Matthews RA, Balmford A (1998). Complementarity and the use of indicator groups for reserve selection in Uganda. Nature 394: 472-475. - doi: 10.1038/28843

Howes S (2009). Cheap but not easy: the reduction of greenhouse gases emissions from deforestation and forest degradation in Papua New Guinea. Pacific Economic Bulletin 25: 130143.

JICA-PNGFA (2014). Capacity development on forest resource monitoring for addressing climate change. JICA-PNGFA Project Final Workshop, Port Moresby (Papua New Guinea) 5-6 Mar 2014. Japanese International Cooperation Agency, web site. [online] URL: http://www. jica.go.jp/png/english/office/topics/140306.html Kati V, Devillers P, Dufrêne $M$, Legakis A, Vokou $D$, Lebru $P$ (2004). Testing the value of six taxonomic groups as biodiversity indicators at a local scale. Conservation Biology 18: 667-675. doi: 10.1111/j.1523-1739.2004.00465.x

Keenan RJ, Fox JC, Brack CL, Saulei S (2011). Native forest management in Papua New Guinea: an introduction. In: "Native forest management in Papua New Guinea: advances in assessment, modelling and decision-making" (Fox JC, Keenan RJ, Brack CL and Saulei S eds). ACIAR Proceedings 135: 32-40.

Keenan RJ, Ambia V, Brack C, Frakes I, Gerrand A, Golman M, Lavong K, Tickle P, Sam N, Vanclay J, Yosi CK (2005). Improved timber inventory and strategic forest planning in Papua New Guinea. Bureau of Rural Sciences, Canberra, Australia and PNG Forest Research Institute, Lae, Papua New Guinea, pp. 12.

Kinch J, Allison A, Kula RG (2010). Papua New Guinea $4^{\text {th }}$ National Report to the CBD. Port Moresby, Papua New Guinea, pp. 86.

Kingston B, Nir E (1998). A report on diagnostic sampling conducted in Oomsis forest. FAO DP/ PNG/84/003, Working Document No. 9. Lae, Morobe Province, Papua New Guinea, pp. 23. Laurence WF, Kakul T, Keenan RJ, Sayer J, Passingan S, Clements R, Villegas J, Sodhi NS (2010). Predatory corporations, failing governance, and the fate of forests of Papua New Guinea. Conservation Letters 4: 95-100. - doi: 10.1111/j.1755-263X.2010.00156.x

Lindemalm F, Rogers HM (2013). Impacts of conventional logging and portable sawmill logging operations on tree diversity in East New Britain, Papua New Guinea. Australian Forestry 64: 2631. - doi: 10.1080/00049158.2001.10676157 Lindenmayer DB (1999). Future directions for biodiversity conservation in managed forests: 
indicator species, impact studies and monitoring programs. Forest Ecology and Management 115: 277-287. - doi: 10.1016/S0378-1127(98)00406$\mathrm{X}$

Melik D (2010). Credibility of REDD and experiences from Papua New Guinea. Conservation Biology 24: 359-361. - doi: 10.1111/j.1523-1739.2010.01 471.x

Myers N, Mittermeier RA, Mittermeier CG, Fonseca GAB, Kent J (2000). Biodiversity hotspots for conservation priorities. Nature 403: 853858. - doi: $10.1038 / 35002501$

Nepstad DC, Verissimo A, Alencar A, Nobre C, Lima E, Lefebvre $P$, Schlesinger $P$, Potter $C$, Moutinho P, Mendoza E, Cochrane M, Brooks V (1999). Large-scale impoverishment of Amazonian forests by logging and fire. Nature 398: 505-508. - doi: 10.1038/19066

Oavika F (1992). Report on the establishment of PSP/TSI in Turama, Papua New Guinea. PNG Forest Research Institute Internal Report, Lae, Papua New Guinea, pp. 25.

Olsen DM, Dinerstein E (1998). The global 2000: a representation approach to conserving the earth's most biologically valuable ecoregions. Conservation Biology 12 (3): 502-515. - doi: 10.10 46/j.1523-1739.1998.012003502.x

Paijmans K (1975). Explanatory notes to the vegetation map of Papua New Guinea. Land Research Series, CSIRO, Melbourne, Australia, pp. 25. [online] URL: http://library.wur.n//WebQue $\mathrm{ry} / \mathrm{clc} / 204135$

Pelissier R, Pascal J-P, Houllier F, Laborde H (1998). Impact of selective logging on the dynamics of a low elevation dens moist ever- green forest in the Western Ghats (South India). Forest Ecology and Management 105: 107-119. - doi: 10.1016/S0378-1127(97)00275-2

Pielou EC (1966). The measurement of diversity in different types of biological collections. Journal of Theoretical Biology 13: 131-144. - doi: 10.1016/0022-5193(66)90013-0

Pimm SL, Raven PH (2000). Extinction by numbers. Nature 403: 843-845. - doi: $10.1038 / 3500$ 2708

PNGFA (1991). Forestry Act 1991. No 30, Hohola, Independent State of Papua New Guinea, 21 April 1993.

PNGFA (1996). Procedures for exporting logs. Port Moresby, Papua New Guinea, pp. 38.

Pokana JN (2002). Assessing the relationship between the soil groups and species composition in logged-over rainforests of Papua New Guinea. MSc Thesis, School of Agricultural and Forest Sciences, University of Wales, Bangor, UK, pp. 96.

Putz FE, Zuidema PA, Synnott T, Peña-Claros M, Pinard MA, Sheil D, Vanclay JK, Sist P, GorletFleury S, Griscom B, Palmer J, Zagt R (2012). Sustaining conservation values in selectively logged tropical forests: the attained and the attainable. Conservation Letters 5: 296-303. doi: 10.1111/j.1755-263X.2012.00242.x

Saulei SM (1984). Natural regeneration following clear-fell logging operations in the Gogol Valley, Papua New Guinea. Ambio 13: 351-354.

Shannon CE (1948). A mathematical theory of communication. The Bell System Technical Journal 27: 379-423 and 623-656. - doi: 10.1002/ j.1538-7305.1948.tbo1338.x
Shearman P, Bryan J, Ash J, Hunnam P, Mackey $B$, Lokes B (2008). The state of the forests of Papua New Guinea. Mapping the extent and condition of forest cover and measuring the drivers of forest change in the period 19722002. University of Papua New Guinea, Port Moresby, Papua New Guinea, pp. 148.

Shearman P, Bryan J, Ash J, Hunnam P, Mackey B, Lokes B (2009). Forest conversion and degradation in Papua New Guinea 1972-2002. Biotropica 41: 379-390. - doi: 10.1111/j.1744-7429.20 09.00495.x

Stork NE (2010). Reassessing extinction rates. Biodiversity and Conservation 19: 357-371. - doi: 10.1007/s10531-009-9761-9

Supriatna J, De Fretes $\mathrm{Y}$, Mack A, Yeager CP, Olivier S, Burnett JB, Wijayanto I, Suryadi S, Suhandi A (1999). The Irian Jaya priority-setting workshop. Final report, Conservation International, Washington, DC, USA, pp. 71.

Verburg R, Van Eijk-Bos C (2003). Effects of selective logging on tree diversity, composition and plant functional type patterns in a Bornean rainforest. Journal of Vegetation Science 14: 99110. - doi: 10.1111/j.1654-1103.2003.tb02132.x

Verissimo A, Barreto P, Mattos M, Tarifa R, Uhl C (1992). Logging impacts and prospects for sustainable forest management in an old Amazonian frontier: the case of Paragominas. Forest Ecology and Management 55: 169-199. - doi: 10.1016/0378-1127(92)90099-U

Yosi CK, Keenan RJ, Fox JC (2011). Forest dynamics after selective harvesting in Papua New Guinea. Forest Ecology and Management 262: 895-905. - doi: 10.1016/j.foreco.2011.06.007 